\title{
Official Development Aid: Plaster in A Wound? Evidence Using Data From Ethiopia
}

Cherkos Meaza ( $\nabla$ chokemeaza@gmail.com )

University of Verona https://orcid.org/0000-0001-7766-1454

\section{Research Article}

Keywords: Economic Growth, Error Correction Model, Official Development Assistance

Posted Date: July 7th, 2021

DOI: https://doi.org/10.21203/rs.3.rs-666818/v3

License: (9) This work is licensed under a Creative Commons Attribution 4.0 International License. Read Full License 


\title{
Official Development Aid: Plaster in A Wound? Evidence Using Data From Ethiopia
}

\begin{abstract}
The flow of aid to developing countries has increased massively and they receive billions of dollars per year in the form of aid from bilateral and multilateral donors. However, the economic growth achieved by many developing countries, in general, has not been satisfactory. Poverty is still there and resulted in a custom of aid dependence and foster the opportunity for the corrupted political leader. The conclusion on aid effectiveness is doubtful among economists, found to be inconclusive.

This paper intends to see how the Ethiopian economy is reacting to the flow of foreign aid coming from the rest of the world viz-a-viz the current most prestigious and influential arguments against and pro-effectiveness of aid. A time series on important parameters extending from 1981 to the most current 2017 is used and an econometrics technique ECM is employed to examine the short-run dynamics and long-run relationship among the variables.

The result of the short-run dynamics showed that aid has a negative and statistically significant impact on economic growth. However, the impacts turn to be positive in the long run. economic growth measured by the real GDP adjusts to its long-run equilibrium with an average speed of about 25.7 percent annually and it will roughly take it about 4 years to restore to equilibrium, ceteris paribus.
\end{abstract}

Keywords: Economic Growth, Error Correction Model, Official Development Assistance

\section{Introduction ${ }^{1}$}

In recent years, aid to developing countries has increased massively and they receive billions of dollars per year in the form of aid from donors. According to Dambisa Moyo's speech, more than $\$ 1$ trillion in development-related aid has been transferred from rich countries to Africa in the past fifty years. However, the economic growth achieved by many developing countries, in general, has not been satisfactory. Thus, the actual macro impact of foreign aid on economic growth has been an area of controversy. The developmental objectives that aid is expected to achieve are premised on the fundamental assumption that aid works in reducing poverty (Niyonkuru F., 2016). Yet the effectiveness of aid in reducing poverty and achieving other related developmental outcomes has been questioned for many decades.

The conclusion on aid effectiveness is doubtful among economists, found to be inconclusive, and has been a controversial subject for years. various time series and cross-country studies have come up with different results and different policy inferences. A very important question nowadays is that does aid works? if it does not work, the justification is that there is no reason to provide aid, it would be withheld and at the extreme aid agencies should be closed down. The argument is also extended how far is official development aid effective and how is possible to see its impact at a macro level (Riddell, 2014)

\footnotetext{
${ }^{1}$ In this term paper, the term foreign aid, , refers only to Official Development Assistance (ODA). According to DAC-OECD, ODA is ....... "the flow of official financing to the developing world that is concessional in character; grants and loans with at least a 25 percent grant component. ODA is generally administered with the objective of promoting the economic development and welfare of developing countries, and comprises both bilateral aid that flows directly from donor to recipient governments and multilateral aid that is channeled through an intermediary lending institution like the WB and IMF".
} 
One argument that usually come into the mind of researchers who studied the effectiveness of aid is that there should be a mechanism to look at the after and before or situations in the country with and without aid. In other words, the correct economic approach to capture aid-effectiveness is the difference between actual macroeconomic performance observed with aid programs and the performance that would have been expected in the absence of such aid. According to Haque et al, (1998), to be able to understand the impact of an action on an event, the basic question that requires being answered is that what would have happened to the event if an action did not take place given that all other circumstances are kept the same.

A compliment to those points, donors necessitate those recipient countries to made structural reforms or policies that the donors think those reforms promote economic growth or development. After the economic and debt crisis of the developing world in the 1970s and 1980s, the major donors, WB and IMF made a major change in aid policy to these least developing countries in crisis. They change their main principle towards more conditional assistance and recommend a reform called the Structural Adjustment program. However, those conditionality has been the main sources of controversies where some scholars led to argue those conditionality introduced by the institutions have been counterproductive and affected negatively the economic growth and development of the recipient countries.

As it is said before the issue of aid effectiveness is not conclusive and stay a subject of controversy but apart from that majority of the scholars studying the impact of official development assistance on economic growth is undertaken using a cross-sectional method and thus this paper has tried to see the impact of ODA using a specific country over extended periods because, it is believed that each country is unique, the role of aid can be understood best through careful analysis of individual countries. The study has extended to include the current dominating debts on the effectiveness of aid; " Aid Works by Jeff Sachs" , "Dead Aid" by Dambisa Moyo ${ }^{3}$, The white man Burden" by William Easterly among others. In a broad stroke, the paper has attempted to investigate the shortrun dynamics and the long-run relationship between development aid flowing from donors and the economic growth of Ethiopia.

\section{Literature Review}

Even though there are massive researches on the relationship between development aid and economic growth, there has not been an agreement between them letting the subject matter continue being debatable and results are generally inconclusive. While researchers like Jensen and Paldam(2003), Mosley (1980), Voivodas(1973), Mosley et al.(1987), Boone (1996)conclude Aid is not effective in stimulating growth others like Papanek (1973), Bhattarai (2005) and Tadesse.T (2011) found that aid affects economic growth positively. In the following few sections, the arguments for and against the necessity of aid are presented.

\subsection{Arguments for and Against Aid}

\footnotetext{
2 Jeff Sachs' in his book "The End of Poverty" ( 2005) advocates a big-Push" featuring large increase in aid to finance a package of complementary investments in order to end world poverty.

${ }^{3}$ Moyo is international economist who become influential after writing a book "Dead Aid: Why Aid Is Not Working and How There Is a Better Way for Africa(2009)"
} 


\subsubsection{Aid Works by Jeffrey Sachs}

Sachs is among the publicly well-known economists that support the finding aid has been effective. According to him, those current arguments we observe against the effectiveness of aid are wrong because there are many circumstances that aid helps the poor around the world and it was specifically effective in saving the lives of millions of people. He further tried to oppose the conclusions made by those prominent scholars like William Easterly by articulating, we have to further amplify the success of aid and summed up "Aid skeptics are wrong". The arguments of those two scholars have received huge attention concerning the effectiveness of aid and thousands of academicians have attempted to explore the causality relationship between aid and economic growth using different econometrics analysis techniques.

Gomanee et al (2005) have investigated the effect of foreign aid on growth in twenty-five selected SSA countries using the Residual Regressors Approach (RRA). They have identified three mechanisms of transmission where aid can be channeled to economic growth: investment ${ }^{4}$, import financing, and government spending. The researchers found a significant and positive effect of foreign aid on economic growth. Bhattarai (2005) uses time-series data of Nepal for the period 1970-2002 and employs cointegration and the error correction mechanism as the estimation procedure to examine the effectiveness of aid and its link with domestic saving, investment, and per capita growth. The results show that aid has a positive and significant relationship between per capita real GDP, savings, and investment in the long run.

\subsubsection{Arguments Against Aid}

It is clear that both W. Easterly and D. Moyo are among the top economists who argue and conclude against the effectiveness of aid in the sense that either aid adversely affects the economic growth of developing countries or it has been a wastage for the developed economies as it does not achieve the development objectives.

\section{A. The white man Burden by William Easterly}

W. Easterly has rejected the poverty trap thoughts of J. Sachs and showed that the aid granted by the developed economies has brought so many bad things and very few good things in the economy of LDCs. Easterly signalized that many foreign aid programs not only fail to bring improvement but also, often get in the way of finding local solutions to the problems that stand in the way of poorer nations' growth. Easterly addresses the frequent negative outcomes of loans and grants provided by the WB, IMF, and USAID. Those programs mainly emphasize the best interest of the wealthy and are guided by what the rich perceive to be what is best for the recipients of the monies, but not necessarily what would benefit them the most.

\section{B. Dead Aid by D. Moyo}

Moyo has articulated in her book and personal web page by concluding aid so far was not effective in terms of achieving its economic objective and helping the poor to run away out of poverty she

\footnotetext{
${ }^{4}$ Gomanee et al (2005) identify investment as the most significant transmission mechanism among others.
} 
instead summarized [....] "Poverty levels continue to escalate and growth rates have steadily declined and millions continue to suffer. Annoyingly drawing a sharp contrast between African countries that have rejected the aid route and prospered and others that have become aid-dependent and seen poverty increase, Moyo made brighter how excessive dependence on aid has caught developing nations in a dangerous and dreadful circle of aid dependency, corruption, market distortion, and further poverty, leaving them with nothing but the "need" for more aid".

Moyo has said that the economic objective of aid flowing to Africa is very interesting however, there lacks coordination among the donors themselves. The donors do not have where the money sent to the poor countries is spent which finally leads the political leaders to be corrupted. She strongly argued in many public debates that official aid is easy money that facilitates corruption and distorts economies, creating a custom of dependency on aid and economic laziness.

In addition to those well-known scholars, many empirical works found an adverse effect of aid on the economic growth of developing countries. Tadesse T (2011) has studied the investment and economic impact of foreign aid in Ethiopia for the period 1970 to 2009 using multivariate cointegration analysis. Foreign aid is effective in enhancing growth. However, the aid-policy interaction term has produced a significant negative effect on growth which means bad policies negatively affect the aid effectiveness.

Another study by Liew et al (2012) employed panel data methods, more specifically Pooled OLS, Random Effects, and Fixed Effects to investigate the association between foreign aid and economic growth of East African countries. The results suggested that foreign aid has a significant negative influence on economic growth for these countries.

\subsubsection{Aid and growth: No relationship}

Wondwesen(2003) analyzed the impact of foreign aid on growth on annual data covering the period 1962/63 to 2000/01 applying Johansen's maximum likelihood technique found that aid has a significant contribution to investment both in the short run and long run. Aid is found to be ineffective in enhancing growth. However, he found that when aid has interacted with policy, the growth impact of aid is found to be significant. Rajan (2005) studied the effects of aid on growth using cross-sectional and panel data for selected poorer countries. The researcher found little robust evidence of a positive (or negative) relationship between aid inflows and economic growth. Rajan also found no evidence that aid works well in better policy or geographical environments, or that certain forms of aid work better than others.

\subsection{The Perspective of Ethiopia}

Ethiopia has registered vigorous economic growth for more than 15 days starting in 2003/04 onward. The real GDP of the country has increased on average by $10.65^{5}$ percent per year during 2005-2017 which makes Ethiopia one of the fastest-growing countries in the world. The growth decelerated in 2017 and grows by only 7.7 percent where Industry, mainly construction, and services accounted for most of the growth. Agriculture and manufacturing made lower contributions to growth in 207/18 compared to the previous year. Ethiopia's growth has exceeded its regional peers (Sub-Saharan African Countries) and other developing and emerging market countries. Rapid growth, driven by large public investment and growing services, has contributed

${ }^{5}$ According to the data extracted from World Bank (See Appendix) 
to impressive progress in poverty reduction, measured as a change in the share of the population living below the poverty line. In this regard, Ethiopia has outperformed most SSA countries and If the country can continue its historically impressive growth performance, it could potentially achieve the goal which is reaching middle-income status by 2025 .

Although the high import vigorous of the economy, limited capacity to produce capital goods, low levels of domestic savings, and limited capacity to generate foreign exchange are considered to be the bottlenecks to the development effort of Ethiopia (Meaza, C. 2018). All these factors have provided an objective justification for the huge inflow of foreign aid. Consequently, foreign aid has been playing a critical role in the development efforts of Ethiopia since the 1960s. Those development aids are considered as the means to finance deficits, filling the trade gap, saving gap by expanding the level of investment of the country(Alemu 2009).

History showed that Ethiopia is one of the major recipients of international aid. According to the OECD-DAC Statistics, Ethiopia has received a total of around US\$3.6 billion over the periods 1981-2017 making the top 6th receipt after Egypt, South Africa, Nigeria, Morocco, and Tanzania. The main driving force for donors to resume their assistance was the implementation of the Sustainable Development Poverty Reduction Program (SDPRP) in 2001/02, Plan for Accelerated and Sustained Development to End Poverty (PASDEP) in 2005/06 and Growth and Transformation Plan-I (GTP-I) in 2010/11 and Growth and Transformation Plan-II (GTP-II) in 2015/16. Therefore, the adoption of the above poverty reduction strategy papers (PRSPs) and structural adjustment programs by the government has been important steps forward in attracting large and growing official development assistance.

\section{Data Sources and Methodology}

\subsection{Model Specification}

In exploring whether development aid is causing growth in Ethiopia, this paper has used secondary sources of time series data covering the period from 1981 to 2017 . The official development assistance data is taken from the OECD database for the periods in consideration. The fact that labor force survey in Ethiopia did not take place yearly, it is a difficult task to construct a time serious econometrics model. Therefore, it is common to use the percentage of active labor force ranging from the age 15 to 64 to the total population is used to measure the labor force component of the model. The data for the labor force as a percentage of the total population is taken from the world development indicator. Whereas the data for the real GDP, the share of expenditure on education to GDP (which measures the amount of human capital), gross capital formation (that measures the amount of physical capital) are extracted from the National Bank of Ethiopia (NBE) ${ }^{6}$. The Solow model is employed to estimate the growth effect of foreign aid. The neoclassical Solow model articulated economic growth has resulted from the combination of capital and labor. The total factor productivity which is referred to as Solow residual is comprised of all other factors that account for output growth. Having said this, the GEM for this study can be represented in a CRS Cobb-Douglas production form concerning capital and labor as follows.

$\mathrm{Y}_{\mathrm{t}}=\mathrm{Z}_{\mathrm{t}} \mathrm{F}\left(\mathrm{L}_{\mathrm{t}}, \mathrm{K}_{\mathrm{t}}\right)$

${ }^{6}$ NBE: National bank of Ethiopia 
Where: $Y_{t}, K_{t}, L_{t}$ and $Z t$ represents total output, physical capital, labor force, and technological progress or total factor productivity (TFP) at time $t$ respectively. Increase in $\mathrm{Z}$ results in an increase in the productivity of $\mathrm{K}$ and $\mathrm{L}$. The above production function can be rewritten in a mathematical presentation to determine the contribution of each variable to economic growth. Suppose an economy can be described by a Hicks neutral Cobb-Douglas production function of the form, $\mathrm{Y}_{\mathrm{t}}=\mathrm{Z}_{\mathrm{t}} \mathrm{L}_{\mathrm{t}}^{\alpha} \mathrm{K}^{\beta}{ }_{\mathrm{t}}$

Where: $0<\alpha<1$ and $0<\beta<1$

The coefficients $\alpha$ and $\beta$ represent the marginal effects of labor and capital on output respectively. In the case of a Cobb-Douglas production function, neutral and labor-augmenting technological progress are equivalent. The basic Solow model is extended to allow for technological progress.

Therefore if $Z_{t}=A_{t}^{\alpha}$ then,

$Y_{t}=\left(A_{t} L_{t}\right)^{\alpha} K^{\beta}$

Given the capital and labor inputs, an improvement in technology leads to an increase in output. In general technological progress can be labor-augmenting,capital-augmenting, or neutral. The paper extends the Cobb-Douglas production function into a detailed version by assuming that TFP is affected by aid flow, international trade, and skilled human power. Morrisey (2001) has pointed that foreign aid can contribute to economic growth through an increase in physical and human capital investment, increases the capacity to import capital goods or technology, and is associated with technology transfer. International trade is believed to contribute a positive impact on economic growth by efficient allocation of internal and external resources, the shift of technological advancements. Similarly, the more skilled human power in a country, the higher the possibility will be to invent and innovate new goods and services. Writing the technological progress as a function of trade openness, development aid, skilled human power (Human capital) is therefore given as;

$\mathrm{A}_{\mathrm{t}}=\mathrm{F}\left(\mathrm{AID}_{\mathrm{t}}, \mathrm{OPEN} \mathrm{t}, \mathrm{H}_{\mathrm{t}}\right)$

Where: AID $_{\mathrm{t}}, \mathrm{OPEN}_{\mathrm{t}}$, and $\mathrm{H}_{\mathrm{t}}$ are official development aid, trade openness measured as the ratio of trade (import and export) to GDP and skilled human power at time t respectively.

The above expression can be arranged as follows

$A_{t}=\omega A I D_{t}^{\varphi} O P E N_{t}^{\gamma} H_{t}^{\sigma}$

Where: $\omega$ is time-invariant constant

$0<\varphi<1,0<\gamma<1$ and $0<\sigma<1$

Upon substitution of the expression 4 for TFP into the Solow growth model of 2, we will have the following general appearance.

$Y_{t}=\omega A I D_{t}^{\varphi} O P E N_{t}^{\gamma} H_{t}^{\sigma} \mathrm{L}^{\alpha} \mathrm{K}^{\beta}{ }_{\mathrm{t}}$ 
The study specifies the model to be estimated by transforming into natural logarithmic form, therefore the above equation can be explained as;

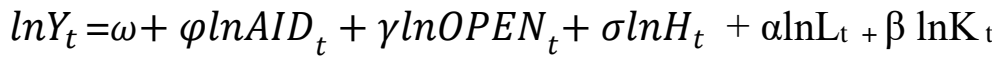

With $\ln Y_{t}$ representing the log of national output proxied by the real GDP time series data and the others are similar to the previous notation. RGDP is the most common measurement for the economic growth of countries. Practically, economic growth can be measured using different variables in different research (Ray, 2012) depending on the relevance of the subject matter. However, for simplicity, this paper has used RGDP as a measurement.

To find out the long and short-run dynamics between official development aid and economic growth, this study employs time series econometrics: Error Correction Model. With minor changes, the final model to be used in this estimation is therefore

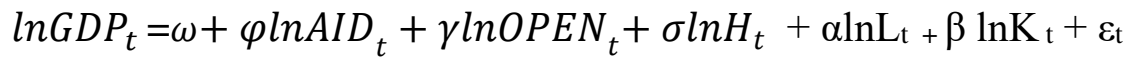

In this specific paper, there are five deterministic sources of economic growth as presented in the above expression which are labor, physical capital, official development aid, trade openness, and human capital. The sign of the parameter $\varphi$, which is the marginal effect of foreign aid on economic growth is the parameter of interest that this paper highly emphasizes. Since all variables are expressed in terms of natural logarithms then the coefficients can be interpreted as elasticities and the variables are expressed in growth terms.

\subsection{Unit Root Test for Stationarity}

The basic starting point of a time series data is checking whether the data in hand is stationary or not. The majority of economic variables are non-stationary (Meaza, C. 2018) at their level. However, in few cases, those time series data set can be changed into stationary if growth is used. According to A.H. Studenmund (2014), any time series whose mean and variance do not change with time is stationary series. In other words, if both mean and variance are not varying over time and the correlation coefficient of a variable and their lagged variables depends on the lag lengths, then the time series is said to be stationary time series. Otherwise, if either of the above properties is violated, that is, if either mean and variance change with time then the series is non-stationary (ibid). If a non-stationary variable is being regressed on another non-stationary dependent variable, the result will lead us to a spurious regression (M. Verbeek, 2004) where inferences based on such regression are confusing and estimators are false estimators.

To make sure that the regression result we obtained is not spurious, it is recommendable to use a stationary test aka "Unit root test" as it is indicated in A.H. Studenmund (2014). Henceforward, after having all variables included in the specified model being stationary, the problem of spurious regression will not be our stress. The most commonly used non-stationary tests include the DFtest, ADF-test ${ }^{7}$, PP tests, KPSS test, and others where the former test is being used in this paper

\footnotetext{
${ }^{7}$ Augmented Dickey Fuller test of non-stationary usually takes three different forms (M. Verbeek, 2004) including without constant term, with constant term and with both constant term and trend being added. No matter what, the decision of test is similar and the same.
} 
which postulates there is unit root against the alternative hypothesis of the null-hypothesis is not true.

\subsection{Johansen Approach Test of Cointegration}

After the non-stationarity test(unit-root test) is performed, the next task is testing for cointegration between the variables in the model given that all the variables are I(1). According to A.H. Studenmund (2014), not all non-stationary time series data set leads to unacceptable or incorrect estimators. Two or more variables which are I(1) can be cointegrated provided that the linear combination of the variables is $\mathrm{I}(0)$ in which those circumstances indicate the presence of a longrun relationship between the non-stationary variables. The existence of long-run associations between the variables in the model in turn has its repercussion for the short-run behavior of the variables for the reason that it will develop the variables to the long-run equilibrium relationship through a mechanism called error correction mechanism.

Provided that the study is a multivariate analysis, the study locks itself to the bivariate analysis. The reason is that Engle granger is criticized in case there are more than two variables in the model. Therefore it is recommendable to stick to the Johansen cointegration test only. This bivariate analysis provides a preliminary image of how the flow of aid is affecting the growth of the economy.

\subsection{Error Correction Model (ECM)}

The third and final step after ensuring the existence of a long-run relationship between the variables in the model is simply to run the error correction model. The error correction model estimation shows us the short-run dynamics of the variables (individual effects of explanatory variables) and the speed of adjustment back to its long-run equilibrium as dependent variables do not adjust automatically or immediately.

Roughly speaking, in the cointegrating regression, the residuals are constrained by the cointegrating relationship; hence, they are never far from the regression line. In a spurious regression, the residuals would most likely be often far away and increasingly far with time from the regression line. Because the two cointegrated variables are trended, every extra observation spreads out the range of the sample then supports an accurate valuation than when they are stationary variables necessarily constrained to a narrower range of variation.

\section{Results and Discussion}

\subsection{Introduction}

Previous studies on aid effectiveness were mostly based on cross-country data; few studies used time-series data for individual countries. It is generally believed that single-country time-series analysis is more useful, as it can capture country-specific features that may not be found in a crosscountry analysis. As the discussion in the previous section, time-series data may produce spurious relations if the variables under study are linked to common factors. according to Engle and Granger (1987), the direct application of ordinary least squares or generalized least squares to nonstationary data produces regression results that are misspecified or spurious. 


\subsection{Stationarity Test Analysis}

Before performing the test for cointegration and running the regression for the long-run equation specified in the previous section, it is necessary to examine whether the data series is stationary or not using the ADF test. Testing for stationarity is useful to avoid any spurious inferences. The ADF test for the stationarity shows that all the variables are non-stationary at their level and we cannot reject the null hypothesis of a unit root. However, all of the series are stationary after first differencing and therefore they all are integrated order of one, I(1).

In the case of testing variables in their level, the ADF test is performed with constant as well as with constant and trend whereas the ADF test of unit root is done without constant and with constant for the differenced variables. The detail of the test is summarized in the table below.

Table: Augmented Dickey-Fuller Test of variables for unit root

\begin{tabular}{|c|c|c|c|c|c|}
\hline \multirow[t]{2}{*}{ Variables } & \multirow{2}{*}{$\begin{array}{l}\text { Test } \\
\text { P-Value }\end{array}$} & \multirow{2}{*}{$\begin{array}{l}\text { Order of } \\
\text { Integration }\end{array}$} & \multicolumn{3}{|c|}{ ADF Test of Stationarity/Unit Root } \\
\hline & & & With constant & Without constant & With constant \& trend \\
\hline \multirow[t]{2}{*}{$\operatorname{lnRGDP}$} & Level & $\mathrm{I}(1)$ & 0.98880 & 0.97960 & 0.96160 \\
\hline & First difference & & $0.004012 * * *$ & $0.01573^{* *}$ & $0.03998 * *$ \\
\hline \multirow[t]{2}{*}{$\ln$ AID } & Level & $\mathrm{I}(1)$ & 0.98220 & 0.54860 & 0.19120 \\
\hline & First difference & & $0.00000 * * *$ & $0.00000 * * *$ & $0.00000 * * *$ \\
\hline \multirow[t]{2}{*}{$\operatorname{lnOPEN}$} & Level & $\mathrm{I}(1)$ & 0.80680 & 0.63480 & 0.18770 \\
\hline & First difference & & $0.00000 * * *$ & $0.00000 * * *$ & $0.00000 * * *$ \\
\hline \multirow[t]{2}{*}{$\ln \mathrm{H}$} & Level & $\mathrm{I}(1)$ & 0.99960 & 0.99550 & 0.50480 \\
\hline & First difference & & 0.13480 & $0.005487 * * *$ & $0.01267 * *$ \\
\hline \multirow[t]{2}{*}{$\ln \mathrm{l}$} & Level & $\mathrm{I}(1)$ & $0.02604 * *$ & $0.006258^{* * *}$ & 0.1437 \\
\hline & First difference & & $0.00000 * * *$ & $0.00000 * * *$ & $0.004112 * * *$ \\
\hline \multirow[t]{2}{*}{$\operatorname{lnK}$} & Level & $\mathrm{I}(1)$ & 0.12710 & 0.72350 & 0.47260 \\
\hline & First difference & & $0.004969 * *$ & $0.00000 * * *$ & 0.21180 \\
\hline
\end{tabular}

Sources: Author calculation using GRETL

$*$,** and $* * *$ representing level of significance at $10 \%, 5 \%$ and $1 \%$ respectively. ${ }^{8}$

\subsection{Co-Integration Analysis}

As discussed in the previous section, cointegration among the variables reflects the presence of long-run relationships in the system. We need to test for cointegration because differencing the variables to get stationarity generates a model that does not show the long-run behavior of the variables. Hence, testing for Cointegration is the same as testing for the long-run relationship.

\subsubsection{Johansen's Cointegration Test Result}

Engle-Granger test of cointegration is applicable in case we have bivariate analysis however it is not recommendable to use it if we are having multivariate analysis. Therefore, to avoid the criticism of the EG test of cointegration for multivariate analysis, a Johansen test is used to

${ }^{8} \mathrm{H}_{0}=$ The variables are not stationary and $\mathrm{H}_{1}=$ The variables are stationary 
determine how many cointegrating vectors there are for a set of variables. The cointegration test proposed by Johansen (1988) and Johansen and Juselius (1990) requires that the optimal lag length must be determined before testing. The optimal lag length is determined from the unrestricted vector auto-regression equation that minimizes the Akaike Information Criterion (AIC) or Schwarz Information Criterion (SIC) or Hannan-Quinn Criterion (HQC). As presented in the table below, all the information criteria showed that the maximum lag length to be used in the cointegration test is 2 .

Table: Lag Length selection? Using the different Information criteria

\begin{tabular}{cccccc}
\hline lags & loglik & $\mathrm{p}(\mathrm{LR})$ & $\mathrm{AIC}$ & $\mathrm{BIC}$ & $\mathrm{HQC}$ \\
\hline 1 & 36.89207 & & -1.805755 & -1.439321 & -1.684292 \\
\hline 2 & 41.67394 & 0.00198 & $\mathbf{- 2 . 0 4 2 1 2 1 *}$ & $\mathbf{- 1 . 6 2 9 8 8 3 *}$ & $\mathbf{- 1 . 9 0 5 4 7 6 *}$ \\
\hline 3 & 41.89887 & 0.50240 & -1.993679 & -1.535637 & -1.841851 \\
\hline 4 & 41.99439 & 0.66205 & -1.937150 & -1.433303 & -1.770139 \\
\hline 5 & 43.50906 & 0.08177 & -1.969316 & -1.419665 & -1.787123
\end{tabular}

Source: Sources: Author calculation using GRETL

Up to now, the task has been started by testing for the stationarity of the variables included in the model. The following table summarizes this test. The trace and Lmax test statistics results show that there is a significant long-run relationship between aid and economic growth. That is, rank equals to zero implies that the null hypothesis of there is no cointegration between the variables is tested against the alternative hypothesis of there is one cointegrating relationship. This is what exactly presented in the table: there is one cointegrating relation which is significant at $1 \%$.

Table: Johansen test for cointegration

\begin{tabular}{|c|c|c|c|c|c|c|c|c|c|}
\hline \multirow[t]{2}{*}{ Rank } & \multicolumn{2}{|c|}{ Hypothesis } & \multirow[t]{2}{*}{ Eigenvalue } & \multirow[t]{2}{*}{ Trace test } & \multirow[t]{2}{*}{ p-value } & \multirow{2}{*}{$\begin{array}{l}\text { Result of } \\
\mathrm{H}_{0}\end{array}$} & \multirow[t]{2}{*}{ Lmax test } & \multirow[t]{2}{*}{ p-value } & \multirow{2}{*}{$\begin{array}{l}\text { Result } \\
\text { of } \mathrm{H}_{0}\end{array}$} \\
\hline & Null & Alternate & & & & & & & \\
\hline 0 & $\mathrm{H}_{0}=0$ & $\mathrm{H}_{1}=1$ & 0.81704 & 123.40 & 0.0001 & Reject & 59.448 & 0.0000 & Reject \\
\hline 1 & $\mathrm{H}_{0}<=1$ & $\mathrm{H}_{1}=2$ & 0.59461 & 63.951 & 0.1334 & Accept & 31.601 & 0.0896 & Reject \\
\hline 2 & $\mathrm{H}_{0}<=2$ & $\mathrm{H}_{1}=3$ & 0.39983 & 32.350 & 0.5967 & Accept & 17.869 & 0.5176 & Accept \\
\hline 3 & $\mathrm{H}_{0}<=3$ & $\mathrm{H}_{1}=4$ & 0.23455 & 14.481 & 0.8141 & Accept & 9.3554 & 0.8014 & Accept \\
\hline 4 & $\mathrm{H}_{0}<=4$ & $\mathrm{H}_{1}=5$ & 0.13607 & 5.1255 & 0.7941 & Accept & 5.1193 & 0.7278 & Accept \\
\hline 5 & $\mathrm{H}_{0}<=5$ & $\mathrm{H}_{1}=6$ & 0.00017671 & 0.0061854 & 0.9373 & Accept & 0.0061854 & 0.9373 & Accept \\
\hline
\end{tabular}

Source: Author calculation using GRETL

\footnotetext{
${ }^{9}$ The asterisks indicate the best (that is, minimized) values of the respective information criteria, $\mathrm{AIC}=$ Akaike criterion, BIC = Schwarz Bayesian criterion and HQC = Hannan-Quinn criterion.
} 


\subsection{The Long-Run Estimation}

Since the variables are cointegrated then one can determine the long-run estimates for the relationship between official development assistance and economic growth. The equation below presents the normalized cointegrating coefficients guided by the results of the cointegration tests.

$$
l R G D P_{t}=523+6.7984 l_{A I D}+12.6957 l O P E N_{t}-8.511655 l H_{t}-139.333 l L_{t}+2.39865 l K_{t}
$$

$$
\begin{array}{llll}
(1.2570) \quad(1.7938) & (1.5990) \quad(34.2025) \quad(2.4142)
\end{array}
$$

As presented in the above equation of the long-run equation, most of the signs of the explanatory variable are not different from the expected. The parameter of interest in this estimation is the impact of aid on the economic growth of the country measured by the real gross domestic product. It is evident that there is a strong positive individual effect of official development aid on economic growth and therefore according to this study, aid has been working in stimulating the economy of Ethiopia.

This finding is consistent with studies including by Badri B. (2005), Birara (2011), Papanek (1973), and others. If the physical damage is deep, putting "plaster in a wound" may at least minimize the pain but can not be a long-lasting solution because, at some point in time, the wound may worsen and start again. Similarly, foreign aid may not a sustainable solution but still, it is contributing a lot in developing countries by saving millions of lives, as the case for Ethiopia, it is also making the economy step forward, at last, according to this study.

The question here is that can the economy would be better than this, had not the country receive billions of dollars? And are the country going to fully rely on aid to finance any gaps and stimulate the economy and stay under the trap of this dependence? What would happen if there was no aid coming from the developed economies? Does the money provide what is expected from it in fostering growth? It is undeniable that there are rural areas with almost no access to education transport and health centers. In such worst circumstances, the intervention of developed countries through aid to build the infrastructure will save the people from the tragedy of life.

Apart from this Trade openness and Physical capital, have a positive impact on economic growth. Most of the industries in developing countries are indeed small and medium enterprises with limited capacity to compete with larger and Multinational companies and that is why most of the economies remain closed and protected. However, this has impeded the economy not to grow. Unless those industries are exposed to international competition, they would simply decide to reap the fruit from the protection by the government and will not grow into bigger companies.

\subsection{Short-Run Dynamics and Error Correction Model}

Having a cointegrated variable are found, it is time to proceed to the estimation of the Error Correction Model representing the short-run relationship among the variables. The table summarizes the error correction model and the short-run effects of the explanatory variables on the economic growth of Ethiopia. The idea that the Error Correction Model coefficient is negative and less than one, is economically and statistically meaningful. Therefore, according to the regression, the error correction term -0.257613 explains that the economic growth measured by the real GDP adjusts to its long-run equilibrium with an average speed of about 25.7 percent annually and it will roughly take it about 4 years to restore to equilibrium, ceteris paribus. 


\title{
Table : Error Correction Model and Short Run Elasticities
}

\author{
Observations 1983-2017 $(\mathrm{T}=35)$
}

Dependent variable: d_1_RGDP

HAC standard errors, bandwidth 2 (Bartlett kernel)

\begin{tabular}{lccccc}
\hline & Coefficient & Std. Error & t-ratio & $p$-value \\
\hline d_AID_1 & -0.00016166 & $5.5687 \mathrm{e}-05$ & -2.9022 & 0.0071 & $* * *$ \\
\hline d_1_OPEN_1 & 0.315448 & 0.0636318 & 4.9574 & $<0.0001$ & $* * *$ \\
\hline d_1_H_1 & 0.0405904 & 0.0877405 & 0.4626 & 0.6472 \\
\hline d_1_L_1 & 4.77403 & 2.84641 & 1.6772 & 0.1046 \\
\hline d_1_K_1 & 0.00594397 & 0.0781824 & 0.0760 & 0.9399 & $* * *$ \\
\hline ECM_1 & -0.257613 & 0.0914055 & -2.8184 & 0.0088 & $*$ ** \\
\hline d_1_RGDP_1 & 0.837056 & 0.178913 & 4.6786 & $<0.0001$ & $* * *$ \\
\hline
\end{tabular}

\begin{tabular}{lrlr} 
Mean dependent var & 0.067052 & S.D. dependent var & 0.132264 \\
Sum squared resid & 0.273805 & S.E. of regression & 0.098887 \\
R-squared & 0.635967 & Adjusted R-squared & 0.557960 \\
F(7, 28) & 16.67941 & P-value(F) & $1.84 \mathrm{e}-08$ \\
Log-likelihood & 35.22421 & Akaike criterion & -56.44841 \\
Schwarz criterion & -45.56098 & Hannan-Quinn & -52.69007 \\
rho & -0.100132 & Durbin-Watson & 2.171971 \\
\hline
\end{tabular}

Source: Author calculation using GRETL

This estimation is not only about the estimation of the adjustment speed, it also shows the short dynamics which are the individual effects of the explanatory variables. The previous year's RGDP level has a positive and statistically significant impact on the current year's RGDP. Every 1\% increase (decrease) in the last year's RGDP, will cause the current RGDP to increase (decrease) by about 0.84 percent on average, holding other things to be constant. In the short run, the previous year's ODA exists to affect the current year RGDP adversely and it is also statistically significant. The impact of aid wilt not to be effective immediately where those impacts might be observed with longer possible time. In contrast to this, variables like physical capital, human capital, and labor input are not statistically significant in the short run. However, trade openness has a positive and statistically significant impact on the current year's RGDP of the country.

Looking at the diagnosis, the paper has performed all the necessary tests to ensure the robustness of the regression/estimation and as a result, the model specification used does not have any statistical problem and as a result, this can be taken as a good representation of the variables. The goodness of the fit, both $\mathrm{R}^{2}$ and Adjusted $\mathrm{R}^{2}$ of the model are supporting a considerable association of the variables. According to $\mathrm{R}^{2}$ and Adjusted $\mathrm{R}^{2}, 63.6 \%$ and $55.8 \%$ of variations in the dependent variable are explained by the variations in the explanatory variables respectively. The Breusch-Godfrey test for autocorrelation, Breusch-Pagan test for heteroskedasticity, and the normality test also showed that the estimation is meaningful.

\section{Conclusion and Recommendation}


The study confirmed that ODA and the economic growth of Ethiopia are negatively related in the short run but in the long run, official development assistance has a positive and significant effect on the economic growth of the country. Furthermore, it is found that the variables physical capital and trade openness exists to affect economic growth Positively. Who knows best about a patient: the doctor or the patient? Therefore, whatever the degree of aid effectiveness is, it is found that aid is helping the poor by saving the lives of millions of people.

The economy of developing countries is characterized by a low level of saving, a huge trade deficit, and budget deficits. As a means to finance those gaps, the presence of development aids undeniable. Despite this, every dollar coming in the form of has to be invested in those sectors that are very productive: agriculture, infrastructural developments, and other areas in the case of Ethiopia. furthermore, the government has to attempt to decrease the bureaucratic and rent-seeking culture of leaders and institutions which conceal the effectiveness of aid.

A complement to this, donors should also have clear coordination and accountability among themselves where the money is spent, track the progress of every dollar granted to the developing countries in general. If not, those billions of dollars may attract extra interest from the governing body to be corrupted. It should not be granted in a reciprocity principle where donors give aid to countries in an exchange or expectation of something to get back from them.

Finally, further investigations on the effectiveness of ODA, national data (reported by NBE) as well as figures reported by WB, IMF, OECD, and others need to be accurate and consistent.

Note: The researcher has no conflict of interest.

\section{References}

- Alemu Getnet (2009), “A Case Study On Aid Effectiveness In Ethiopia; Analysis Of The Health Sector Aid Architecture", Wolfensohn Center For Development Working Paper 9

- Badri Prasad Bhattarai (2005), "The Effectiveness of Foreign Aid: A Case Study of Nepal", University of Western Sydney, Sydney, Australia.

- Birara Yimer. (2011), "The Impact Of Foreign Aid On Economic Growth In Ethiopia”, Master thesis, AAU.

- Bitew Tadesse (2014), "Foreign Aid and Economic Growth in Ethiopia", Unpublished Thesis, Addis Ababa University

- Cherkos Meaza (2018) An Economic Analysis of the Impact of Globalization in Ethiopian Economy: Application of ECM: Journal of Economics and Sustainable Development; ISSN 22221700 (Paper) ISSN 2222-2855 (Online): Vol.9, No.7

- Chung Yee Liew, Masoud Rashid Mohamed and Said Seif Mzee (2012), " The Impact of Foreign Aid on Economic Growth of East African Countries", Journal of Economics and Sustainable Development, Vol.3, No.12

- Craig Burnside and David Dollar (1997), “Aid, Policies and Growth”, Policy Research Working Paper 1777, World Bank, Washington, D.C

- Craig Burnside and David Dollar (2000), “Aid, Policies and Growth", American Economic 
- Gustav Papanek (1973),“Aid, Foreign Private Investment, Savings, and Growth in Less Developed Countries”, Journal of Political Economy 81(1): 120-130.

- IMF (2015), IMF, Ethiopia's Country Report No. 15/326

- Karuna Gomanee, Sourafel Girma and Oliver Morrissey (2005), "Aid and Growth in Sub Saharan Africa: Accounting for Transmission Mechanisms", Research paper No. 2005/60, United Nation University.

- Kibrom Tafere and Alemayehu Geda (2011), "Official Development Assistance (Aid) and its Effectiveness in Ethiopia", IAES working paper A07/2011

- Niyonkuru F. (2016) Failure of Foreign Aid in Developing Countries: A Quest for Alternatives. Bus Eco J 7:231

- Paul Mosley, John Hudson and Sara Horrell (1987), "Aid, the Public Sector and the Market in Less Developed Countries", The Economic Journal, Vol. 97, No. 387

- Peter Boone (1994), "The Impact of Foreign Aid on Savings and Growth", London School of Economics

- Raghuram Rajan and Arvind Subramanian (2005), "Aid And Growth: What Does The CrossCountry Evidence Really Show?", NBER Working Paper No 11513, Massachusetts Avenue, Cambridge Review, Vol. 90, pp. 847-68

- Roger Riddell (2014), “Does Foreign Really Work?”, Oxford Policy Management, oxford, UK

- Tassew Tadesse (2011), "Foreign Aid and Economic Growth in Ethiopia" MPRA Paper No. 33953.

- UNCTAD (2006), "Doubling Aid; Making The Big-Push Work", Geneva, UNCTAD Secretariat

- William Easterly (2003), “Can Foreign Aid Buy Growth?”, Journal of Economic Perspectives Volume 17

- Wondwossen Tadesse. (2003), "An Empirical Investigation of the Aid-Growth Relationship in Ethiopia.”, Addis Ababa University

\section{APPENDECIES}

GDP Growth and amount of ODA(Billion of USD) from 2005/06 to 2017/18

\begin{tabular}{|c|c|c|c|c|c|c|c|c|c|c|c|c|c|}
\hline Year & 2005 & 2006 & 2007 & 2008 & 2009 & 2010 & 2011 & 2012 & 2013 & 2014 & 2015 & 2016 & 2017 \\
\hline $\begin{array}{l}\text { GDP } \\
\text { Growth }^{10}\end{array}$ & 13.57 & 11.82 & 10.83 & 11.46 & 10.79 & 8.80 & 12.55 & 11.18 & 8.65 & 10.58 & 10.26 & 10.39 & 7.56 \\
\hline $\mathrm{ODA}^{11}$ & 1.22 & 1.04 & 1.19 & 1.71 & 2.06 & 2.11 & 1.79 & 1.92 & 1.87 & 2.22 & 2.67 & 2.72 & 3.19 \\
\hline
\end{tabular}

Source: World Bank Data and OECD-DAC Data Base

\section{Graphical representation of variable}

\section{Time series Plot of Stationarity test at level}

\footnotetext{
${ }^{10}$ Taken from National Bank of Ethiopia

${ }^{11}$ Data extracted from OECD data base
} 
I L

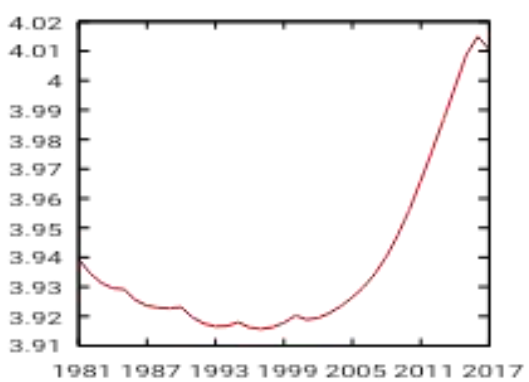

I_K

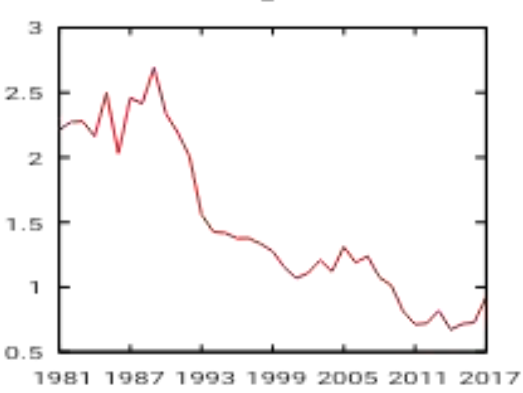

d_I_L

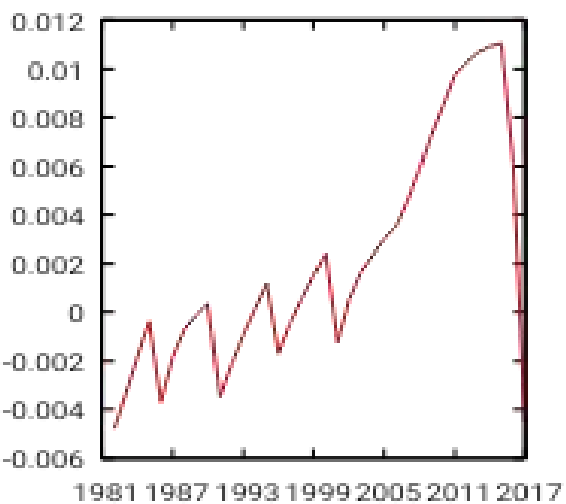

d_I_K

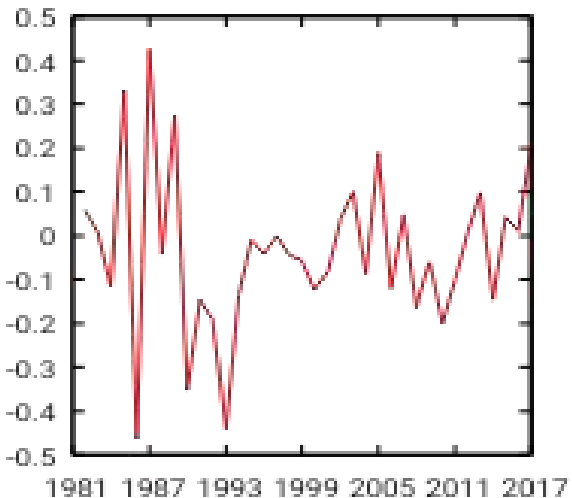

I_OPEN

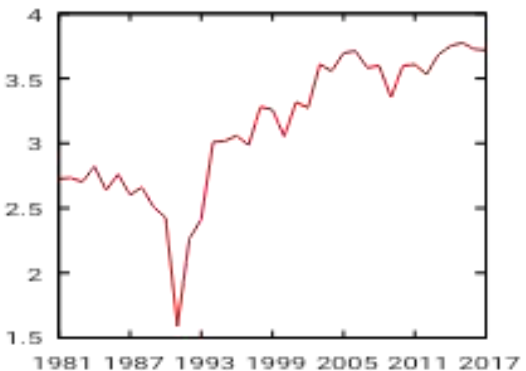

LFGDP

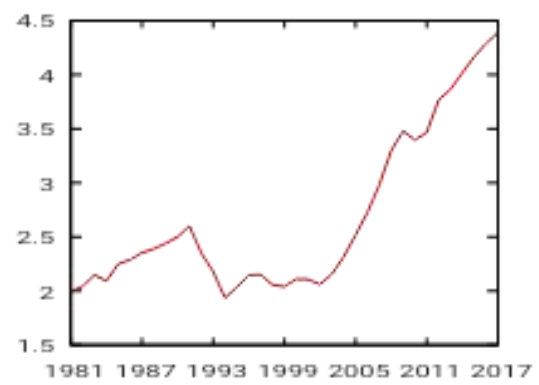

d_I_OPEN

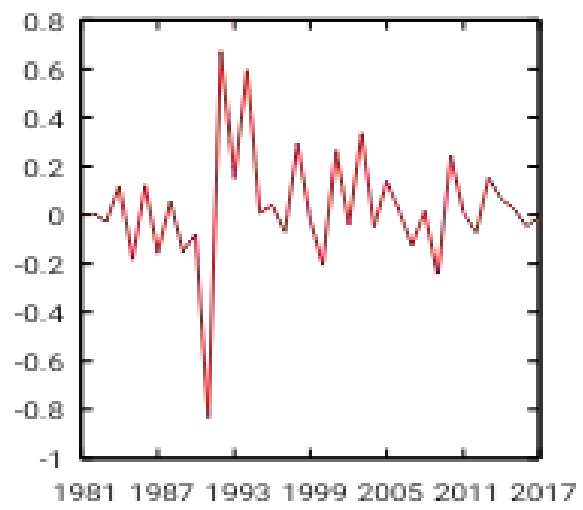

d_I_RGDP

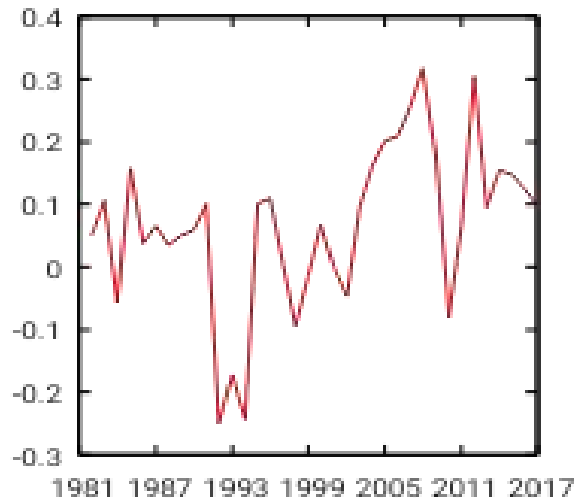

I_AID

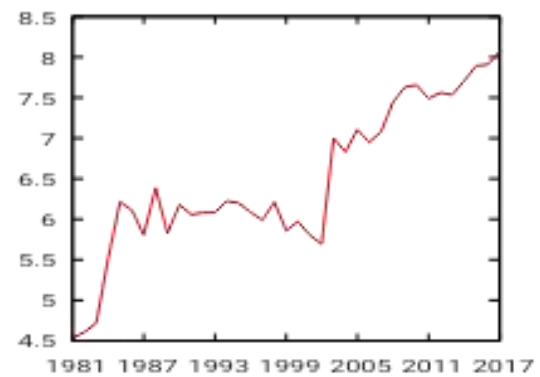

$1 \_$H

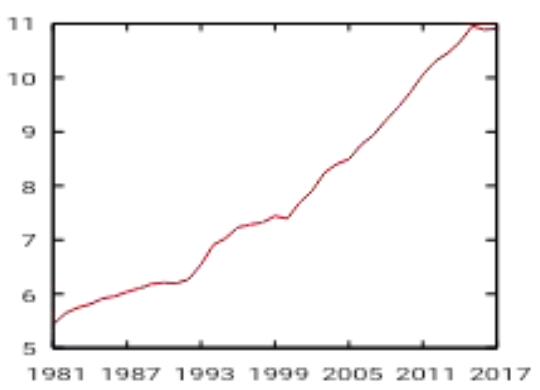

d_I_AID

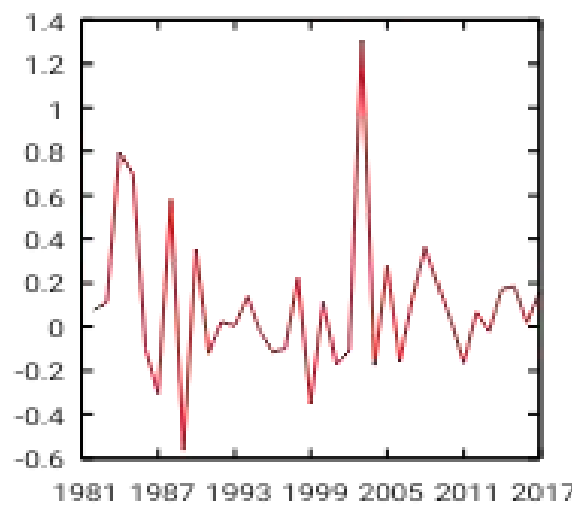

d_I_H

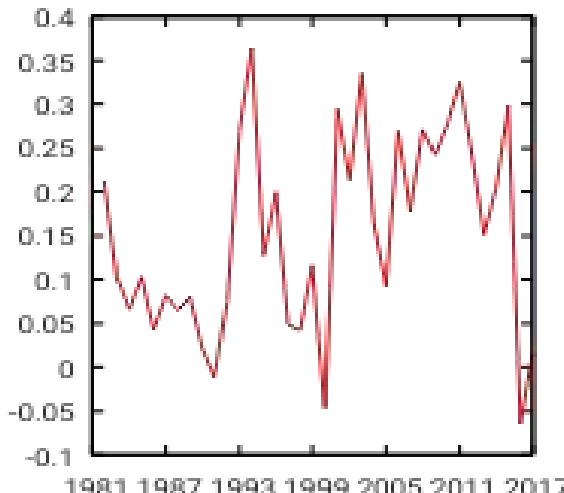




\section{Regressions and Tests}

Model 1: OLS, using observations 1981-2017 $(\mathrm{T}=37)$

Dependent variable: 1_RGDP

HAC standard errors, bandwidth 2 (Bartlett kernel)

\begin{tabular}{l|cc|c|cl}
\hline & Coefficient & \multicolumn{1}{c}{ Std. Error } & t-ratio & $p$-value & \\
\hline const & -42.8919 & 6.57883 & -6.5197 & $<0.0001$ & $* * *$ \\
$\operatorname{lnOPEN} \mathrm{t}_{\mathrm{t}}$ & -0.395325 & 0.059423 & -6.6527 & $<0.0001$ & $* * *$ \\
$\ln _{\mathrm{AID}}$ & 0.118651 & 0.0508013 & 2.3356 & 0.0262 & $* *$ \\
$\operatorname{lnK}_{\mathrm{t}}$ & 0.453664 & 0.0938353 & 4.8347 & $<0.0001$ & $* * *$ \\
$\ln _{\mathrm{t}}$ & 0.415556 & 0.0718424 & 5.7843 & $<0.0001$ & $* * *$ \\
$\ln \mathrm{L}_{\mathrm{t}}$ & 10.6908 & 1.79492 & 5.9561 & $<0.0001$ & $* * *$ \\
\hline
\end{tabular}

\begin{tabular}{lrlr} 
Mean dependent var & 2.678333 & S.D. dependent var & 0.757305 \\
\hline Sum squared resid & 0.376539 & S.E. of regression & 0.110211 \\
R-squared & 0.981763 & Adjusted R-squared & 0.978821 \\
F $(5,31)$ & 466.0511 & P-value(F) & $3.44 \mathrm{e}-28$ \\
Log-likelihood & 32.37085 & Akaike criterion & -52.74170 \\
Schwarz criterion & -43.07619 & Hannan-Quinn & -49.33415 \\
rho & 0.431037 & Durbin-Watson & 1.131614 \\
\hline
\end{tabular}

\section{RAMSEY RESET test for specification}

Test statistic: $\mathrm{F}=3.703814$, with $\mathrm{p}$-value $=\mathrm{P}(\mathrm{F}(2,29)>3.70381)=\mathbf{0 . 0 3 6 9}$

\section{Breusch-Pagan test for heteroskedasticity}

Test statistic: $\mathrm{LM}=12.312484$, with $\mathrm{p}$-value $=\mathrm{P}($ Chi-square $(5)>12.312484)=\mathbf{0 . 0 3 0 7 4 8}$

\section{$\underline{\text { Test ofr Normality of Residual }}$}

Test for null hypothesis of normal distribution:

Chi-square $(2)=4.962$ with $\mathrm{p}$-value $\mathbf{0 . 0 8 3 6 7}$

\section{Breusch-Godfrey test for autocorrelation up to order 2}

using observations 1981-2017 $(\mathrm{T}=37)$

Dependent variable: uhat

Test statistic: $\mathrm{LMF}=3.717208$, with $\mathrm{p}$-value $=\mathrm{P}(\mathrm{F}(2,29)>3.71721)=\mathbf{0 . 0 3 6 5}$

Alternative statistic: $\mathrm{TR}^{\wedge} 2=7.549823$, with $p$-value $=\mathrm{P}($ Chi-square $(2)>7.54982)=\mathbf{0 . 0 2 2 9}$

Ljung-Box Q' = 9.2479,

with $\mathrm{p}$-value $=\mathrm{P}($ Chi-square $(2)>9.2479)=\mathbf{0 . 0 0 9 8 1}$ 
Identification: beta is exactly identified

Johancen nomglization restriction inposed

\begin{tabular}{|c|c|c|c|c|c|c|}
\hline beta & Coef. & Std. Err. & $\mathbf{z}$ & $p s|x|$ & [55! Conf. & Interval] \\
\hline _cel & & & & & & \\
\hline IRGDP & 1 & - & - & - & - & - \\
\hline IAm & 6.7983日 & 1.257039 & 5.91 & a. arat & 4. 394693 & 9.262131 \\
\hline 10PES & 12 _ 69573 & 1. 793837 & 7. 0 B & a_trata & 9.179875 & 16.21159 \\
\hline IH & -8.511655 & 1.599033 & -5.32 & a. arat & -11.6957 & -5.377607 \\
\hline H & -139 & 39_20257 & -4.07 & a cara & -206.3689 & -72 .29729 \\
\hline $\mathbf{H R}$ & 2 _.398649 & 2 - 914237 & t. 99 & a.320 & -2 . 339168 & 3.130466 \\
\hline _cons & 523 . atrat 6 & - & - & - & - & - \\
\hline
\end{tabular}

